\title{
THE CURRENT ACCOUNT AND THE INTEREST DIFFERENTIAL IN CANADA
}

\author{
by Michel Normandin
}

Cahier de recherche $n^{\circ}$ IEA-04-09

October 2004

ISSN : 0825-8643

\footnotetext{
Copyright (C) 2004. HEC Montréal.

Tous droits réservés pour tous pays. Toute traduction ou toute reproduction sous quelque forme que ce soit est interdite.

Les textes publiés dans la série des Cahiers de recherche HEC n' engagent que la responsabilité de leurs auteurs.

La publication de ce Cahier de recherche a été rendue possible grâce à des subventions d' aide à la publication et à la diffusion de la recherche provenant des fonds de HEC Montréal.

Direction de la recherche, HEC Montréal, 3000, chemin de la Côte-Sainte-Catherine, Montréal (Québec) Canada H3T 2 A7.
} 


\title{
The Current Account and the Interest Differential In Canada
}

\author{
Martin Boileau and Michel Normandin
}

October 2004

\begin{abstract}
For post-1975 Canadian data, we document the joint behavior of output, the current account, and the interest differential at the business cycle frequency. We also interpret the joint behavior using a simple small open economy model. Our simple model assumes that agents have access to world international financial markets, but face country-specific interest rate on their holdings of world assets. The interest differential depends negatively on the country's net foreign asset position. We find that our simple model matches the Canadian data remarkably well.
\end{abstract}

JEL Classification Codes: E32, F41, G15.

Keywords: International Real Business Cycle, Small Open Economy, Habit Formation.

Boileau: Department of Economics and CIRPÉE, University of Colorado, 256 UCB, Boulder CO 80309 USA. Tel.: 303-492-2108. Fax: 303-492-8960. E-mail: martin.boileau@colorado.edu. Normandin: Department of Economics and CIRPÉE, HEC Montréal, 3000 Chemin de la CôteSainte-Catherine, Montréal Que. H3T 2A7 Canada. Tel.: 514-340-6841. Fax: 514-340-6469. E-mail: michel.normandin@hec.ca. 


\section{Introduction}

The analysis of the current account and the real interest rate differential have been important enterprises. From a policy maker's point of view, the current account is important, because it provides information about the amount of foreign resources that must be borrowed to fund domestic investment, and as such it informs on the changes in foreign indebtedness. The interest differential is important, because they yields information on the real cost of borrowing at home, relative to the real cost of borrowing abroad. It is generally agreed that (monetary) stabilization policies must alter the interest differential to affect the course of the business cycle in open economies.

Interestingly, the vast majority of academic studies ignore the relation between the current account and the interest differential. This is surprising, because current accounts and interest rates should jointly adjust to ensure the equilibrium of the world capital market. Instead, most of the literature on the current account aims to either test the intertemporal approach to the balance of payments (which generally assumes a constant interest rate) or to test the extent of international capital mobility. Likewise, most of the literature on the interest differential aims at testing real interest parity and at investigating the role played by the real exchange rate.

There are some notable exceptions. The empirical studies of Bernhardsen (2000) and Lane and Milesi-Ferreti (2002) do link the current account and the interest differential. Using panel data for 12 European countries, Bernhardsen (2000) finds that a deterioration in the current account raises the interest differential. Using panel data for 66 countries, Lane and Milesi-Ferreti (2002) find that the interest differential is inversely related to the net foreign asset position. This suggests that a deterioration of the current account that worsens the net foreign asset position raises the interest differential. Our own previous theoretical work, Boileau and Normandin (2004), studies the relation between the business cycle fluctuations of the current account and those of the interest differential. We show that a simple multi-country model where international financial markets are incomplete and costly to operate yields an interest differential that is inversely related to the net foreign asset position. We also show that our multi-country model provides a good description 
of the relation between the current account and the interest differential in 10 developed countries.

In this paper, we study the joint business cycle fluctuations of output, the current account, and the interest differential in post-1975 Canadian data. It is often argued that the Canadian economy is better represented as a small open economy rather than a large economy. If this is the case, our two-country model might not apply to the Canadian case. For this reason, we study a small open economy model of Canada similar to those in Letendre (2004) and Nason and Rogers (2002). The small open economy is populated by a representative consumer, a firm, and a government. Agents in the small open economy have access to world international financial markets. In using these markets, agents generate movements in the current account. In their international financial transactions, however, agents face a country-specific real return on their holdings of (world) foreign assets. The difference between the country-specific return and the world return is the interest differential. In using international financial markets, agents also affect movements in the interest differential.

We study three versions of the small open economy model. The first version uses our baseline parametrization. It assumes that the interest differential depends exclusively on the net foreign asset position. As in Senhadji (1997), we assume that a worsening of the small open economy's net foreign asset position raises the country-specific return above the world return and thus raises the interest differential. That is, agents in the small open economy face an upward sloping supply of foreign funds. When the small open economy borrows on financial markets (a current account deficit), it can do so at an increasing cost of borrowing. This assumption is supported by the empirical work on capital flows by Lane and Milesi-Ferreti (2002).

The second version uses the debt-output ratio parametrization. The Debt-Output Ratio version modifies the Baseline version by assuming that the interest differential depends on the net foreign asset to output ratio. We study this version of the interest differential because it is widely used in literature (see for example Letendre 2004, Nason and Rogers 2002, and Schmitt-Grohé and Uribe 2003). In this version, the interest differential worsens with a deterioration in the net foreign asset position. A rise in home output, however, 
improves the ability to support a higher foreign debt and reduces the foreign premium or interest differential.

Finally, the last version uses the habit formation parametrization. The Habit Formation version modifies the Baseline version by assuming that the consumer's preferences exhibit habit formation. We study this version of consumer's preferences because it has been shown important in understanding asset returns and the business cycle (see for example Boldrin, Christiano, and Fisher 2001). Habit formation is often perceived as essential to explain observed asset returns. It would then seem an important component to explain the interest differential.

We find that the Baseline version of the model offers a good description of the joint business cycle features of output, the current account, and the interest differential for post1975 Canadian data. In particular, the Baseline version correctly predicts that the current account and the interest differential are less volatile than output, and that the current account is countercyclical while the interest differential is procyclical. The Baseline version also correctly predicts the shape of the cross-correlation functions between the current account and the interest differential, between output and the current account, and between output and the interest differential. Importantly, it correctly predicts that correlations between lags of the current account and the interest differential are negative, while the correlations between leads of the current account and the interest differential are positive. This asymmetric shape of the cross-correlation function resembles a horizontal S. This S-curve encompasses the negative relation between the current account and the interest differential discussed in Bernhardsen (2000), Boileau and Normandin (2004), and Lane and Milesi-Ferreti (2002). Admittedly, the Baseline version is not perfect. In particular, it underpredicts the relative volatility of the current account and overpredicts the relative volatility of the interest differential.

In contrast, we find that the Debt-Output Ratio version and the Habit Formation version do not offer a good description. The Debt-Output Ratio version incorrectly predicts that the interest differential is almost as volatile as output and countercyclical. The Habit Formation version of the model also incorrectly predicts that the interest differential is almost as volatile as output. In addition, it incorrectly predicts that the current account 
is procyclical.

Overall, our Baseline version of the small open economy model offers the best description of the business cycle fluctuations of output, the current account, and the interest differential in post-1975 Canadian data. Our results contrast with those in earlier work in two directions. First, the Baseline model is driven almost exclusively by productivity shocks. That is, government expenditures and world real interest rate shocks play only a small role. This contrasts with Nason and Rogers (2002) who argue that government expenditures and world real interest rate shocks are important to explain the Canadian experience. Second, the Baseline model assumes that the interest differential is inversely related to simply the net foreign asset position. This contrasts with Boileau and Normandin (2004) where the differential is as in the Debt-Output Ratio version of the model.

The plan of the paper is as follows. Section 2 presents the small open economy model of Canada. The three versions of the model correspond to three distinct parametrizations. Section 3 presents simulation results for the three versions of the small open economy model. We first study the dynamic responses of output, the current account, and the interest differential to the various shocks in the model. We then study the business cycle statistics generated by the three versions of the model, and we compare these statistics to those of post-1975 Canadian data. Finally, we study the robustness of these results for the Baseline model. Section 4 concludes.

\section{A Small Open Economy Model}

In this section, we develop the small open economy model and discuss its parametrization. The economy is that of a small country open to world financial markets. Financial markets, however, are incomplete. In addition, the agents in the small open economy face a countryspecific interest rate on their net holdings of foreign (world) assets.

\subsection{The Model}

The small country is populated by a representative consumer, whose expected lifetime 
utility is given by

$$
E_{t}\left[\sum_{t=0}^{\infty} \beta^{t} U\left(C_{t}-\psi C_{t-1}, N_{t}\right)\right],
$$

where $E_{t}$ is the conditional expectation operator, $C_{t}$ is consumption, $N_{t}$ is hours worked, and $0<\beta<1$. Similarly to Letendre (2004), we employ GHH preferences (Greenwood, Hercowitz, and Huffman 1988):

$$
u\left(C_{t}-\psi C_{t-1}, N_{t}\right)=\left[C_{t}-\psi C_{t-1}-(\theta / \eta) N_{t}^{\eta}\right]^{\gamma} / \gamma
$$

where $\gamma \geq 1, \psi \geq 0, \theta>0$, and $\eta>1$. Importantly, these preferences exhibit habit formation only when $\psi>0$. GHH preferences play an important role in international business cycle studies. Specifically, Correia, Neves, and Rebelo (1995) show that GHH preferences promote a countercyclical trade balance.

The production technology is constant return to scale in its inputs:

$$
Y_{t}=Z_{t} K_{t}^{\alpha} N_{t}^{1-\alpha}
$$

where $Y_{t}$ is output, $Z_{t}$ is the level of total factor productivity, $K_{t}$ is the capital stock, and $0<\alpha<1$. Capital accumulation follows

$$
K_{t+1}=I_{t}+(1-\delta) K_{t}-\Phi_{t} K_{t}
$$

where $I_{t}$ is investment and $0<\delta<1$. The term $\Phi_{t}$ denotes adjustment costs:

$$
\Phi_{t}=\frac{\phi}{2}\left(\frac{I_{t}}{K_{t}}-\delta\right)^{2},
$$

where $\phi \geq 0$. Investment is costly only when $\phi>0$. As in Baxter and Crucini (1995), we use adjustment costs mainly to contain the re lative volatility of investment.

The current account is given by changes in the net holdings of foreign assets or changes in the net foreign asset position:

$$
X_{t}=B_{t+1}-B_{t}
$$

where $X_{t}$ is the current account and $B_{t}$ is net holdings of foreign assets (the net foreign asset position). Using the definition for the current account, the aggregate resource constraint is

$$
X_{t}=Y_{t}+\left(R_{t}-1\right) B_{t}-C_{t}-I_{t}-G_{t}
$$


where $R_{t}$ is the country-specific gross return on world assets and $G_{t}$ is government expenditures. For simplicity, the government runs a balanced budget, funding its expenditures with nondistortionary (lump-sum) taxes.

The country-specific return $R_{t}$ differs from the world return by

$$
D_{t}=R_{t}-R_{t}^{w}
$$

where $D_{t}$ is the real interest differential and $R_{t}^{w}$ is the world return. As in Boileau and Normandin (2003), Nason and Rogers (2002), and Uribe and Schmitt-Grohé (2003), we model the differential as a function of the net foreign asset position:

$$
D_{t}=-\varphi B_{t} / Y_{t}^{\xi}
$$

where $\varphi \geq 0$ and $\xi \geq 0$. There is no differential when $\varphi=0$. Also, the interest differential is only a function of the net foreign asset position when $\xi=0$. The interest differential is a reduced form formulation to obtain an upward sloping supply of foreign funds. As in Senhadji (1997), this may occur because of an otherwise uncaptured risk premium. As in Boileau and Normandin (2003), it may also occur because international financial markets are costly to operate.

The model has three shocks: productivity $Z_{t}$, government expenditures $G_{t}$, and the world return $R_{t}^{w}$. The shocks are generated by

$$
\begin{aligned}
z_{t} & =\rho_{z} z_{t-1}+\epsilon_{z t}, \\
g_{t} & =\rho_{g} g_{t-1}+\epsilon_{g t}, \\
r_{t}^{w} & =\rho_{r} r_{t-1}^{w}+\epsilon_{r t},
\end{aligned}
$$

where $z_{t}=\ln \left(Z_{t} / Z\right), g_{t}=\ln \left(G_{t} / G\right), r_{t}^{w}=\ln \left(R_{t}^{w} / R^{w}\right)$. The variables $Z, G$, and $R^{w}$ are the steady state values of productivity, government expenditures, and world return. The innovations $\epsilon_{z t}, \epsilon_{g t}$, and $\epsilon_{r t}$ are uncorrelated zero-mean random variables with variances $\sigma_{z}^{2}, \sigma_{g}^{2}$, and $\sigma_{r}^{2}$.

The model is solved using a pseudo-planner's problem. The pseudo-planner chooses consumption, hours worked, investment, and asset holdings to maximize the representative 
consumer's expected lifetime utility (1) subject to the constraints given by equations (2) to (8). Importantly, the pseudo-planner takes the country-specific interest rate as given. The first-order conditions are

$$
\begin{aligned}
\lambda_{t} & =U_{h t}-\psi \beta E_{t}\left[U_{h t+1}\right], \\
U_{N t} & =-\lambda_{t}(1-\alpha) Y_{t} / N_{t}, \\
\lambda_{k t} & =\lambda_{t} /\left[1-\phi\left(I_{t} / K_{t}-\delta\right)\right], \\
\lambda_{t} & =\beta E_{t}\left[\lambda_{t+1} R_{t+1}\right], \\
\lambda_{k t} & =\beta E_{t}\left[\lambda_{t+1} \alpha \frac{y_{t+1}}{k_{t+1}}+\lambda_{k t+1}\left(1-\delta-\Phi_{t+1}+\phi\left(\frac{I_{t+1}}{K_{t+1}}-\delta\right) \frac{I_{t+1}}{K_{t+1}}\right)\right] .
\end{aligned}
$$

where $\lambda_{t}$ and $\lambda_{k t}$ are multipliers associated with the resource constraint (7) and the accumulation equation (4). Also, $U_{h t}$ and $U_{n t}$ are the partial derivatives of $U\left(H_{t}, N_{t}\right)$ with respect to its arguments $H_{t}=C_{t}-\psi C_{t-1}$ and $N_{t}$ :

$$
\begin{aligned}
& U_{h t}=\left[C_{t}-\psi C_{t-1}-(\theta / \eta) N_{t}^{\eta}\right]^{\gamma-1}, \\
& U_{n t}=-\left[C_{t}-\psi C_{t-1}-(\theta / \eta) N_{t}^{\eta}\right]^{\gamma-1} \theta N_{t}^{\eta-1} .
\end{aligned}
$$

Equation (11.1) equates the shadow price of consumption to its marginal benefit. The marginal benefit has two components. The first is the rise in utility following an immediate increase in consumption. The second is the reduction in future utility coming from the future lowering of consumption below its habit level. Equation (11.2) equates the marginal cost of working an extra unit of time to its marginal benefit of higher production. Equation (11.3) translates the shadow price of new capital into its output price. Equation (11.4) equates the marginal cost of purchasing an extra unit of world assets to its discounted expected marginal benefit. Equation (11.5) equates the marginal cost of purchasing an extra unit of capital to its discounted expected marginal benefit of additional future production.

The system that characterizes the equilibrium for this model includes the set of firstorder conditions (11) and the partial derivatives (12). The set is completed by the production function (3), the accumulation equation (4), the definition of the adjustment cost (5), the definition of the current account (6), the aggregate resource constraint (7), the interest differential described by (8) and (9), and the laws of motion for shocks (10). 


\subsection{Parametrization}

The system of equations that characterizes the equilibrium does not yield an analytical solution. The equilibrium must be approximated using numerical methods. For this, we employ the log-linear approximation method described in King, Plosser, and Rebelo (2002). This method linearizes the equations that characterize the equilibrium around the deterministic steady state equilibrium. This linearization requires that values be assigned to all parameters.

We set a number of parameters to the values discussed in Boileau and Normandin (2003). The subjective discount factor is $\beta=0.99$, the coefficient of relative risk aversion is $1-\gamma=2$, the elasticity of labor supply is $1 /(\eta-1)=1.7$, the share of capital is $\alpha=0.36$, the depreciation rate is $\delta=0.025$, and the responsiveness of the interest differential to the net foreign asset position is $\varphi=0.0035$. In addition, we set the share of work parameter $\theta$ to ensure that the time devoted to work is $N=0.30$ in the steady state.

We use the post-1975 Canadian data to set a number of parameters (see Data Appendix). We set the adjustment-cost parameter $\phi$ to ensure that the ratio of the standard deviation of investment to the standard deviation of output is 2.57 as in the Canadian data. We set the steady state level of the output share of government expenditures to $G / Y=21$ percent as in the Canadian data. We set the steady state level of the world real interest rate to ensure that the steady state level of the interest differential is $D=0.235$ percent as in our data. Finally, the parameters of the shock processes are set to their ordinary least squares estimates. The estimates are $\rho_{z}=0.4920, \rho_{g}=0.5140, \rho_{r}=0.7209$, $\sigma_{z}=0.0180, \sigma_{g}=0.0120$, and $\sigma_{r}=0.0013$.

For the remaining parameters, we explore three cases. Each case represents a particular version of the model. The Baseline version assumes no habit formation $\psi=0$. It also assumes that the interest differential depends only on the net foreign asset position $\xi=0$, as in Devereux and Smith (2003). The Debt-Output Ratio version modifies the Baseline version by allowing the interest differential to depend on output. For this, we set $\xi=1$ so that the interest differential depends on the debt to output ratio as in Boileau and Normandin (2003). Finally, the Habit Formation version modifies the Baseline version to allow for habit formation. To do so, we set $\psi=0.90$ as in Boldrin, Christiano, and Fisher 
(2001).

\section{Results}

In this section, we first study the theoretical properties of the small open economy model. We then compare the empirical properties of the model to those of post-1975 Canadian data.

\subsection{Dynamic Responses}

To understand the different versions of the model, we first document the dynamic responses of some key variables to the different shocks.

Figure 1 displays the dynamic responses in all three versions of the model. The shocks come from positive one-standard deviation innovations to productivity, government expenditures, and the world interest rate. The key variables are the logarithm of output $y_{t}=\ln \left(Y_{t} / Y\right)$, the current account (to output ratio) $x_{t}=X_{t} / Y_{t}-X / Y$, and the interest differential $d_{t}=R_{t}-R_{t}^{w}-D$, where $Y, X$, and $D$ are the steady state levels of output, the current account to output ratio, and the interest differential.

At first glance, Figure 1 suggests that the economy is driven mostly by productivity shocks. The responses of the variables are the largest after the productivity shock, small after a government expenditures shock, and almost inexistent after the world interest rate shock. Also, the three versions generate dissimilar responses after the productivity shock, but very similar responses after a government expenditures shock and after a world interest rate shock.

In the Baseline version, an increase in productivity initially raises output, deteriorates the current account, and (with a period lag) raises the interest differential. The higher productivity stimulates both aggregate saving and investment, but saving does not rise enough to fully fund the investment boom. The result is a deterioration of the current account. The deterioration worsens the country's net foreign asset position and eventually pushes up the interest differential. Over time, the investment boom subsides, the current account improves, and the interest differential returns to its steady state. 
An increase in government expenditures generates a deterioration of the current account, and an eventual reduction in output and an increase in the interest differential. Importantly, the shock does not immediately affect output. As discussed in Devereux, Gregory, and Smith (1992) and Letendre (2004), this occurs because GHH preferences ensure that output depends only on productivity and the (predetermined) capital stock:

$$
Y_{t}=\left[\frac{(1-\alpha)}{\theta}\right]^{(1-\alpha) /(\eta-(1-\alpha))}\left(Z_{t} K_{t}^{\alpha}\right)^{\eta /(\eta-(1-\alpha))} .
$$

That is, output does not initially react because neither productivity nor the capital stock initially respond to the increase in government expenditures. The higher government expenditures reduce both aggregate saving and investment, but the effect is larger on saving. The result is a deterioration of the current account. As before, the deterioration eventually worsens the net foreign asset position and raises the interest differential. Facing higher expected home interest rates, firms reduce investment to lower the capital stock. This eventually lowers output. Over time, the increase in government expenditures subsides, the current account improves, and the interest differential returns to its steady state.

Finally, an increase om the world interest rate improves the current account. It eventually lowers output and reduces the interest differential. The increase in the world interest rate makes foreign saving more attractive, and this improves the current account. The improvement of the current account also improves the net foreign asset position, which lowers the interest differential. The home interest rate, however, is raised, as the rise in the world interest rate dominates the reduction in the interest differential. Facing higher expected home interest rates, firms reduce investment to lower the capital stock, which eventually lowers output. Over time, the increase in the world interest rate subsides, the current account deteriorates, and the interest differential returns to its steady state.

In the Debt-Output Ratio version, an increase in productivity also raises output and deteriorates the current account. The increase in productivity, however, reduces the interest differential. As in the Baseline version, the higher productivity generates a deterioration of the current account, which worsens the net foreign asset position. This, however, does not increase the interest differential, because the interest differential is a function of the debt to output ratio. The increase in output works to reduce the interest differential, 
while the worsening of the net foreign asset position works to raise the interest differential. Overall, the rise in output dominates, and the productivity shock generates an initial reduction in the interest differential. As in the Baseline version, an increase in government expenditures generates an eventual and negligible reduction in output, an initial small deterioration of the current account, and an eventual small increase in the interest differential. Also, an increase in the world interest rate eventually reduces output, improves the current account, and eventually reduces the interest differential.

In the Habit Formation version, an increase in productivity again raises output, but the rise in output is accompanied by an improvement in the current account and an eventual reduction in the interest differential. The increase in productivity raises saving by more than investment. This occurs because the habit formation motive forces the consumer to smooth consumption. That is, the increase in productivity raises consumption, but little to avoid the hangover that a future large reduction in consumption would bring. The result is that saving rises more than investment. The improvement in the current account also improves the net foreign asset position, and this eventually reduces the interest differential. As in the Baseline version, an increase in government expenditures generates an eventual and negligible reduction in output, an initial small deterioration of the current account, and an eventual small increase in the interest differential. An increase in the world interest rate eventually reduces output, improves the current account, and eventually reduces the interest differential.

These responses hint at important predicted features. First, these responses suggest that the economy is driven mostly by productivity shocks in all three versions. The responses of the key variables are the largest after the productivity shock, small after a government expenditures shock, and almost inexistent after the world interest rate shock. Second, the importance of productivity shocks suggests that output is more volatile than the current account in all three versions. That is, the responses of output are always larger than those of the current account. Third, the responses also suggest that output is much more volatile than the interest differential in the Baseline version, but only slightly more volatile in the Debt-Output Ratio version and in the Habit Formation version. The response of output is larger than the response of the interest differential in the Baseline 
model, but not clearly so in the Debt-Output Ratio version and in the Habit Formation version. Fourth, the importance of productivity shocks also suggests that the current account is countercyclical in the Baseline version and the Debt-Output Ratio version, but procyclical in the Habit Formation version. That is, the large initial positive response of output is accompanied by a deterioration of the current account in the Baseline version and in the Debt-Output Ratio version, but an improvement of the current account in the Habit Formation version. Fifth, although this is less clear because of the lag, the interest differential appears procyclical in the Baseline version and countercyclical in the DebtOutput Ratio version and in the Habit Formation version. The initial response of output is accompanied by an eventual rise in the interest differential in the Baseline version, but a sharp current reduction in the Debt-Output Ratio version and an eventual reduction in the Habit Formation version.

Overall, the dynamics of the model's key variables provide intuition behind the predicted business cycle features of output, the current account, and the interest differential.

\subsection{Business Cycle Features}

We now compare the business cycle features of post-1975 Canadian data to those of the three versions of the small open economy model. The Canadian quarterly data is fully described in the Data Appendix. In the data, we construct the different variables to reflect the variables from the model. In particular, output $y_{t}$ is the detrended logarithm of real gross domestic product, the current account $x_{t}$ is the detrended current account, and the interest differential $d_{t}$ is the detrended difference between the ex-ante country-specific real interest rate and the ex-ante world real interest rate. As in Taylor (2002), the current account (to output ratio) is the ratio of the current account and gross domestic product. As in Boileau and Normandin (2003), the ex-ante real interest rate is the difference between

the short-term nominal interest rate and the expected inflation rate. As in Nakagawa (2002), the short-term nominal interest rate is the rate on short lending between financial institutions. As in Barro and Sala-i-Martin (1990), the expected inflation rate is the one-quarter ahead predicted inflation rate from a univariate $\operatorname{ARMA}(1,1)$ process. Also, the world interest rate is a weighted average of the country-specific interest rates for 10 
developed countries, where the weights reflect the country's share of the overall real output of the 10 countries. The variables are detrended as in Hodrick and Prescott (1997).

Table 1 reports the salient features of the business cycle fluctuations of consumption, investment, the current account, and the interest differential. These features are presented for Canadian data and the three different versions of the model. The table shows relative volatility and contemporaneous correlations. The relative volatility corresponds to the ratio of the sample standard deviation of a variable to the sample standard deviation of output. The correlations are the sample contemporaneous correlation between a variable and output.

In the Canadian data, consumption, the current account and the interest differential are all less volatile than output. Investment, however, is more volatile than output. In addition, consumption, investment, and the interest differential are procyclical, while the current account is countercyclical.

The simulated statistics from the Baseline version replicate those of the Canadian data remarkably well. That is, consumption, the current account, and the interest differential are less volatile than output, but investment is more volatile than output. Also, consumption, investment, and the interest differential are procyclical, while the current account is countercyclical. The main discrepancies are that the current account is not as volatile as in the data, and that the interest differential is much more volatile than in the data. The simulated relative volatility of the current account is only 25 percent that of the historical relative volatility. The simulated relative volatility of the interest differential is 2.7 times larger than the historical relative volatility.

The simulated statistics for the Debt-Output Ratio version do not replicate those of the Canadian data very well. Recall that the model assumes that the interest differential is a function of the net foreign asset position to output ratio, instead of simply the net foreign asset position. The influence of output on the interest differential appears to deteriorate the ability of the model to explain the Canadian data. In particular, the added output more than doubles the already too large relative volatility of the interest differential. The result is that the simulated relative volatility of the interest differential is now 5.4 times larger than the historical relative volatility. In addition, adding output implies that the 
simulated interest differential wrongly becomes countercyclical.

The simulated statistics for the Habit Formation version also do not replicate those of the Canadian data well. The main benefit of the habit formation assumption is to raise the too low relative volatility of the current account. The simulated relative volatility is now 53 percent that of the historical relative volatility. This benefit, however, comes at a high cost. The assumption of habit formation seriously reduces the relative volatility of consumption, while raising that of the interest differential. The simulated relative volatility of the interest differential is 5.4 times larger than the historical relative volatility. The habit formation assumption also lowers the procyclicality of consumption and the interest differential, while it wrongly makes the current account procyclical.

To further explore the comovements between output, the current account, and the interest differential, Figure 2 displays the dynamic cross-correlation functions between these variables. It shows the cross-correlations between the current account to output ratio and the interest differential, between output and the current account, and between output and the interest differential. The different panels present both the historical crosscorrelations and the simulated cross-correlations produced by the different versions of the model.

In the Canadian data, the cross-correlation function between the current account and the interest differential forms an asymmetric shape, reminiscent of a clock-wise rotated $\mathrm{S}$ or a horizontal S. That is, the correlations between lags of the current account and the interest differential are negative, but the correlations between leads of the current account and the interest differential are positive, with the turning point occuring at the two-quarter lead. The cross-correlation function between output and the current account also has an asymmetric shape. The correlations between lags of output and the current account are mostly positive, while correlations between leads of output and the current account are negative. The turning point occurs at the two-period lag. Also, the current account is a leading indicator of the business cycle (i.e. the largest absolute correlation appears at the 1 period lead). Finally, the cross-correlation function between output and the interest differential resembles a bell with a peak at no leads or lags (the contemporaneous correlation). That is, the interest differential is a coincident indicator of the business cycle. 
The simulated cross-correlation functions for the Baseline version again match those of the Canadian data remarkably well. The model predicts a sharp S curve for the crosscorrelation function between the current account and the interest differential. In particular, the predicted correlations between lags of the current account and the interest differential are negative, and the correlations between leads of the current account and the interest differential are positive. The turning point, however, occurs at the contemporaneous correlation. The model also predicts a sharp asymmetric shape for the cross-correlation function between output and the current account. The correlations between lags of output and the current account are positive, while correlations between leads of output and the current account are positive. The turning point again occurs at the contemporaneous correlation. Finally, the cross-correlation function between output and the interest differential resembles a bell with a positive peak at the two-quarter lag.

The simulated cross-correlation functions for the Debt-Output Ratio version fail to match those of the Canadian data. The model does not predict an asymmetric S-curve for the cross-correlation function between the current account and the interest differential. Instead, it displays a positive peak at the contemporaneous correlation. The Debt-Output Ratio version predicts an asymmetric shape for the cross-correlation function between output and the current account that is very similar to that of the Baseline version. The cross-correlation function between output and the interest differential resembles an inverted bell. Instead of a peak, it has a trough at the contemporaneous correlation.

Finally, the simulated cross-correlation functions for the Habit formation version also fail to match those of the Canadian data. The model predicts an asymmetric S-curve for the cross-correlation function between the current account and the interest differential. The model, however, predicts a tent-shape cross-correlation function for output and the current account. The function peaks at the contemporaneous correlation. Also, the model predicts an asymmetric S-shape for the cross-correlation function of output and the interest differential.

Overall, the simulated business cycle features of the Baseline version of the model match the features of the Canadian data remarkably well. The simulated features of the Debt-Output Ratio model and of the Habit Formation model, however, fail to match the 
features of the Canadian data.

\subsection{Robustness}

We finally verify the robustness of the business cycle statistics produced by the Baseline version of the model. For this purpose, we conduct several experiments with alternative parametrizations of key parameters in the Baseline version. Unless otherwise indicated, we let $\phi=0.393$ as in the Baseline parametrization, instead of varying $\phi$ to match the relative volatility of investment. The different experiments are reported in Table 2 and Figure 3.

The first experiment verifies the effects of changing the coefficient of relative risk aversion. For this experiment, we retain the baseline calibration, but lower the coefficient to $1-\gamma=1$ (logarithmic utility) and raise it to a high of $1-\gamma=10$. These values are consistent with the range studied in Mehra and Prescott (1985). The simulated business cycle statistics and cross-correlation functions are very robust to changes in the coefficient of relative risk aversion. Raising risk aversion merely lowers the relative volatility of consumption, but has otherwise little effects. In part, little occurs because changes in risk aversion do not affect the world real interest rate.

The second experiment verifies the effects of changing the elasticity of labor supply. For this, we lower the elasticity to $1 /(\eta-1)=0.2$ and raise it to $1 /(\eta-1)=2.5$. These values are consistent with the range discussed in Greenwood, Hercowitz, and Huffman (1988). Lowering the elasticity of labor supply seriously reduces the volatility of consumption. To absorb the extra consumption smoothing, both investment and the current account become more volatile. Unfortunately, as in the Habit Formation version, this translates into a more volatile interest differential and a procyclical current account. The result is that the cross-correlation functions resemble those of the Habit Formation version of the model.

The third experiment verifies the effects of changing the cost of adjusting the capital stock. For this experiment, we lower the cost by setting $\phi=0$ and raise it by setting $\phi=0.786$. These values either eliminate the cost or double it (for a given investment). As expected, reducing the cost of adjusting the capital stock substantially raises the volatility of investment. This magnifies the volatility of the current account and of the interest differential. It also sharpens the shapes of the cross-correlation functions. 
Finally, the last experiment verifies the effects of changing the responsiveness of the interest differential to the net foreign asset position. We lower the responsiveness to $\varphi=0.001$ and raise it to $\varphi=0.01$. These values are consistent with those found in Lane and Milesi-Ferreti (2002) and used in Devereux and Smith (2003). The increase in the responsiveness raises the relative volatility of the interest differential and lowers the relative volatility of the current account. It also makes the current account more countercyclical. Finally, the increase in the responsiveness has little effects on the cross-correlation functions.

In sum, these experiments confirm that changes in the parametrization do not substantially improve the fit of the Baseline version of the small open economy model.

\section{Conclusion}

The analysis of the current account and the real interest differential have been important, but separate enterprises. This is surprising, because current accounts and interest rates should jointly adjust to ensure the equilibrium of the world capital market.

For post-1975 Canadian data, we have documented the joint behavior of output, the current account, and the interest differential at the business cycle frequency. We have also interpreted the joint behavior using a simple small open economy model. Our simple model assumes that agents have access to world international financial markets, but face country-specific interest rate on their holdings of world assets. In our framework, the interest differential depends negatively on the country's net foreign asset position.

The small open economy model of Canada is admittedly simple, and can easily be extended. Here is a list of extensions. First, the empirical work in Baxter (1994) suggests that business cycle fluctuations in the real exchange rate are linked to fluctuations in the real interest differential. A potential extension to our analysis would be to explore this link as part of a small open economy model. Second, the empirical work in Lane and Milesi-Ferreti (2002) specifies that the real interest differential is negatively related to the net foreign asset position to exports ratio. A simple extension would be to verify whether this improves the ability of the small open economy model to explain the business 
cycle fluctuations of the current account and the interest differential. This requires that the model distinguishes between imports and exports, which is similar to the model in Senhadji (1997). Third, the empirical and theoretical work in Normandin (1999) suggests that current account deficits and government budget deficits are linked and form twin deficits. Another extension would be to study the relation between the government budget, the current account, and the interest differential. 


\section{Data Appendix}

The quarterly seasonally adjusted measures are constructed for Canada over the 1975-I to 2001-II period. The measures are computed from the International Financial Statistics (IFS) released by the International Monetary Funds, as well as the Main Economic Indicators (MEI) and the Quarterly National Accounts (QNA) published by the Organization for Economic Cooperation and Development.

\section{A.1 Output}

Output is measured by the weighted nominal gross domestic product (GDP) in national currency (source: QNA), deflated by the all-item consumer price index (CPI) for the baseyear 1995 (source: MEI). Following Backus, Kehoe, and Kydland (1992), the output weight is a constant chosen to match the average of our quarterly values of output in 1985 to the yearly data on real GDP obtained from the international prices for 1985, reported by Summers and Heston (1988) (source: variables 1 and 2 in their Table 3).

\section{A.2 Current Account}

The current account is the product of the output weight, the nominal current account in US dollars (source: IFS), and the nominal exchange rate of national currency units per US dollar (source: IFS), divided by the CPI. The current account is further regressed on quarter dummies, because published current-account data are not seasonally adjusted.

\section{A.3 Interest Differential}

The interest differential is the difference between the Canadian interest rate and the world interest rate. The country-specific interest rate is the nominal interest rate minus the expected inflation rate. The nominal interest rate is the one-quarter interbank rate (source: IFS). The expected quarterly inflation rate is the one-quarter ahead forecast formed from a univariate $\operatorname{ARMA}(1,1)$ process. The world interest rate is the sum of the countryspecific interest rates weighted by the country's share of the total output of 10 developed countries. As a group, these countries account for 55 percent of the overall 1990 real gross domestic product of the 116 countries for which data are available in the Penn World Tables (Mark 5.6a). The individual countries are Australia, Austria, Canada, Finland, France, Germany, Italy, Japan, the United Kingdom, and the United States. Germany refers to West Germany and Unified Germany for the pre- and post-1990 periods.

\section{A.4 Consumption, Investment, and Government Expenditures}

Consumption is the output weight times nominal private final consumption expenditures in national currency (source: QNA), deflated by the CPI. Investment is the output weight times nominal gross fixed capital formation in national currency (source: QNA), deflated by the CPI. Government expenditures are the output weight times nominal government

final consumption expenditures in national currency (source: QNA), normalized by the CPI. 


\section{A.5 Productivity}

Total factor productivity is constructed from the production function (3) using the capital share $\alpha=0.36$, and measures of output, capital, and employment. Capital is computed from the capital accumulation equation (4), the adjustment cost equation (5), the depreciation rate $\delta=0.025$, the adjustment cost parameter $\phi=0.393$, the steady state value of capital (for the initial period), and investment. Employment is calculated as the civilian employment index for the baseyear 1995 (source: MEI) times the population in 1985 reported by Summers and Heston (1988) (source: variable 1 in their Table 3). 


\section{References}

Backus, D.K., P.J. Kehoe, and F.E. Kydland, 1992, International real business cycles, Journal of Political Economy 101, 745-775.

Barro, R.J. and X. Sala-i-Martin, 1990, World real interest rates, in O. Blanchard and S. Fischer (eds.) NBER Macroeconomics Annual 1990, Cambridge: MIT Press.

Baxter, M., 1994, Real exchange rates and real interest differentials: Have we missed the business cycle relationship? Journal of Monetary Economics 33, 5-37.

Bernhardsen, T., 2000, The relationship between interest rate differentials and macroeconomic variables: A panel data study for European countries, Journal of International Money and Finance 19, 289-308.

Boldrin, M., L.J. Christiano, and J.D.M. Fisher, 2001, Habit persistence, asset returns and the business cycle, American Economic Review 91, 149-166.

Boileau, M. and M. Normandin, 2003, The dynamics of the current account and interest differential, CIRPÉE Working Paper 03-39.

Correia, I., J.C. Neves, and S. Rebelo, 1995, Business cycles in a small open economy, European Economic Review 39, 1089-1113.

Devereux, M.B. and G.W. Smith, 2003, Transfer problem dynamics: Macroeconomics of the Franco-Prussian war indemnity, mimeo Queen's University.

Devereux, M.B., A.W. Gregory, and G.W. Smith, 1992, Realistic cross-country consumption correlations in a two-country, equilibrium, business cycle model, Journal of International Money and Finance 11, 3-16.

Greenwood, J., Z. Hercowitz, and G.W. Huffman, 1988, Investment, capacity utilization, and the business cycle, American Economic Review 78, 401-417.

Hodrick, R.J. and E.C. Prescott, 1997, Postwar U.S. business cycles: An empirical investigation, Journal of Money, Credit and Banking 29, 1-16.

Lane, P.R. and G.M. Milesi-Ferreti, 2002, Long term capital movements, in B.S. Bernanke and K. Rogoff (eds.) NBER Macroeconomics Annual 2001, Cambridge: MIT Press.

Letendre, M.A., 2004, Capital utilization and habit formation in a small-open economy model, Canadian Journal of Economics 37, 721-741. 
King, R.G., C.I. Plosser, and S.T. Rebelo, 2002, Production, growth and business cycles: Technical appendix, Computational Economics 20, 87-116.

Mehra, R. and E.C. Prescott, 1985, The equity premium: A puzzle, Journal of Monetary Economics 15, 145-161.

Nakagawa, H., 2002, Real exchange rates and real interest differentials: Implications of non-linear adjustment in real exchange rates, Journal of Monetary Economics 49, 629-649.

Nason, J.M. and J.H. Rogers, 2002, The present-value model of the current account has been rejected: Round up the usual suspects, mimeo UBC.

Normandin, M., 1999, Budget deficit persistence and the twin deficits hypothesis, Journal of International Economics 49, 171-194.

Schmitt-Grohé, S. and M. Uribe, 2003, Closing small open economies, Journal of International Economics 61, 163-185.

Senhadji, A., 1997, Sources of debt accumulation in a small open economy, IMF Working Paper 146.

Summers, R. and A. Heston, 1988, A new set of international comparisons of real product and price level: Estimates for 130 countries, 1950-1985, Review of Income and Wealth 34, 1-25.

Taylor, A.M., 2002, A century of current account dynamics, Journal of International Money and Finance 21, 725-748. 


\section{Table 1. Business Cycle Statistics}

\begin{tabular}{|c|c|c|c|c|c|c|c|c|}
\hline & \multicolumn{4}{|c|}{ Relative Volatility } & \multicolumn{4}{|c|}{ Correlation } \\
\hline & $c$ & $i$ & $x$ & $d$ & $(c, y)$ & $(i, y)$ & $(x, y)$ & $(d, y)$ \\
\hline Data & 0.72 & 2.57 & 0.53 & 0.17 & 0.83 & 0.78 & -0.15 & 0.54 \\
\hline Baseline & $\begin{array}{c}0.80 \\
(0.00)\end{array}$ & $\begin{array}{c}2.57 \\
(0.03)\end{array}$ & $\begin{array}{c}0.13 \\
(0.01)\end{array}$ & $\begin{array}{c}0.46 \\
(0.05)\end{array}$ & $\begin{array}{c}0.99 \\
(0.01)\end{array}$ & $\begin{array}{c}0.98 \\
(0.00)\end{array}$ & $\begin{array}{l}-0.42 \\
(0.07)\end{array}$ & $\begin{array}{c}0.44 \\
(0.06)\end{array}$ \\
\hline Debt-Output Ratio & $\begin{array}{c}0.80 \\
(0.00)\end{array}$ & $\begin{array}{c}2.57 \\
(0.03)\end{array}$ & $\begin{array}{c}0.13 \\
(0.01)\end{array}$ & $\begin{array}{c}0.91 \\
(0.03)\end{array}$ & $\begin{array}{c}0.99 \\
(0.00)\end{array}$ & $\begin{array}{c}0.98 \\
(0.00)\end{array}$ & $\begin{array}{l}-0.46 \\
(0.07)\end{array}$ & $\begin{array}{l}-0.90 \\
(0.02)\end{array}$ \\
\hline Habit Formation & $\begin{array}{c}0.17 \\
(0.01)\end{array}$ & $\begin{array}{c}2.57 \\
(0.01)\end{array}$ & $\begin{array}{c}0.28 \\
(0.01)\end{array}$ & $\begin{array}{c}0.91 \\
(0.08)\end{array}$ & $\begin{array}{c}0.42 \\
(0.01)\end{array}$ & $\begin{array}{c}0.99 \\
(0.00)\end{array}$ & $\begin{array}{c}0.97 \\
(0.00)\end{array}$ & $\begin{array}{c}0.14 \\
(0.04)\end{array}$ \\
\hline
\end{tabular}

Note: Entries under relative volatility and correlation refer to the standard deviation of the variable relative to the standard deviation of $y$ and to the contemporaneous correlation between variables. Entries in parenthesis are the standard deviations of the business cycle statistics. The variables are the detrended logarithms of output $(y)$, consumption $(c)$, and investment $(i)$, as well as the detrended ratio of the current account to output $(x)$, and the detrended interest differential $(d)$. The detrending method is the HodrickPrescott filter. The interest differential is constructed from ex-ante real interest rates, using a one-quarter ahead predicted inflation rate from an $\operatorname{ARMA}(1,1)$ process. 
Table 2. Business Cycle Statistics: Sensitivity of the Baseline Parametrization

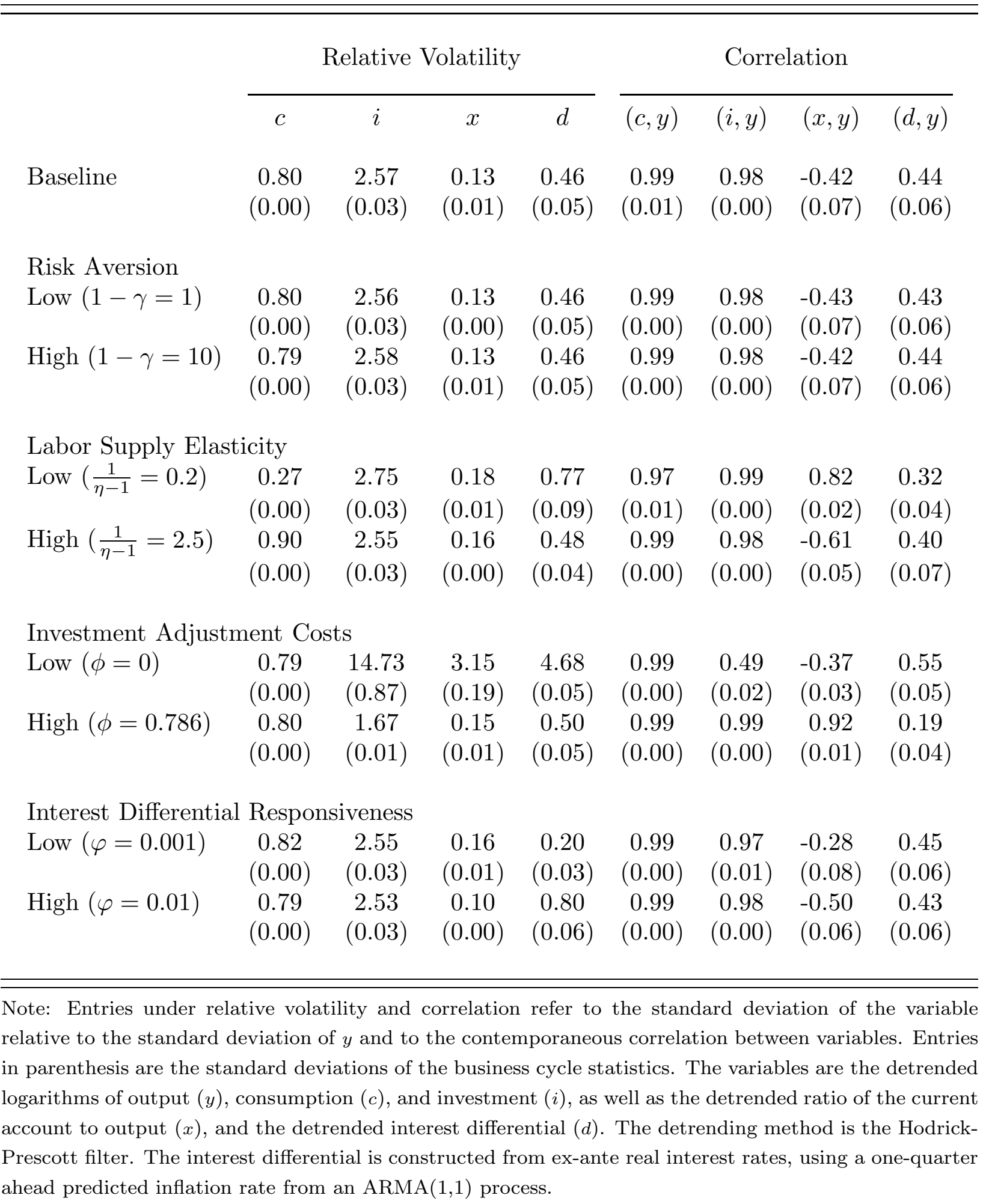




\section{Figure 1. Dynamic Responses}
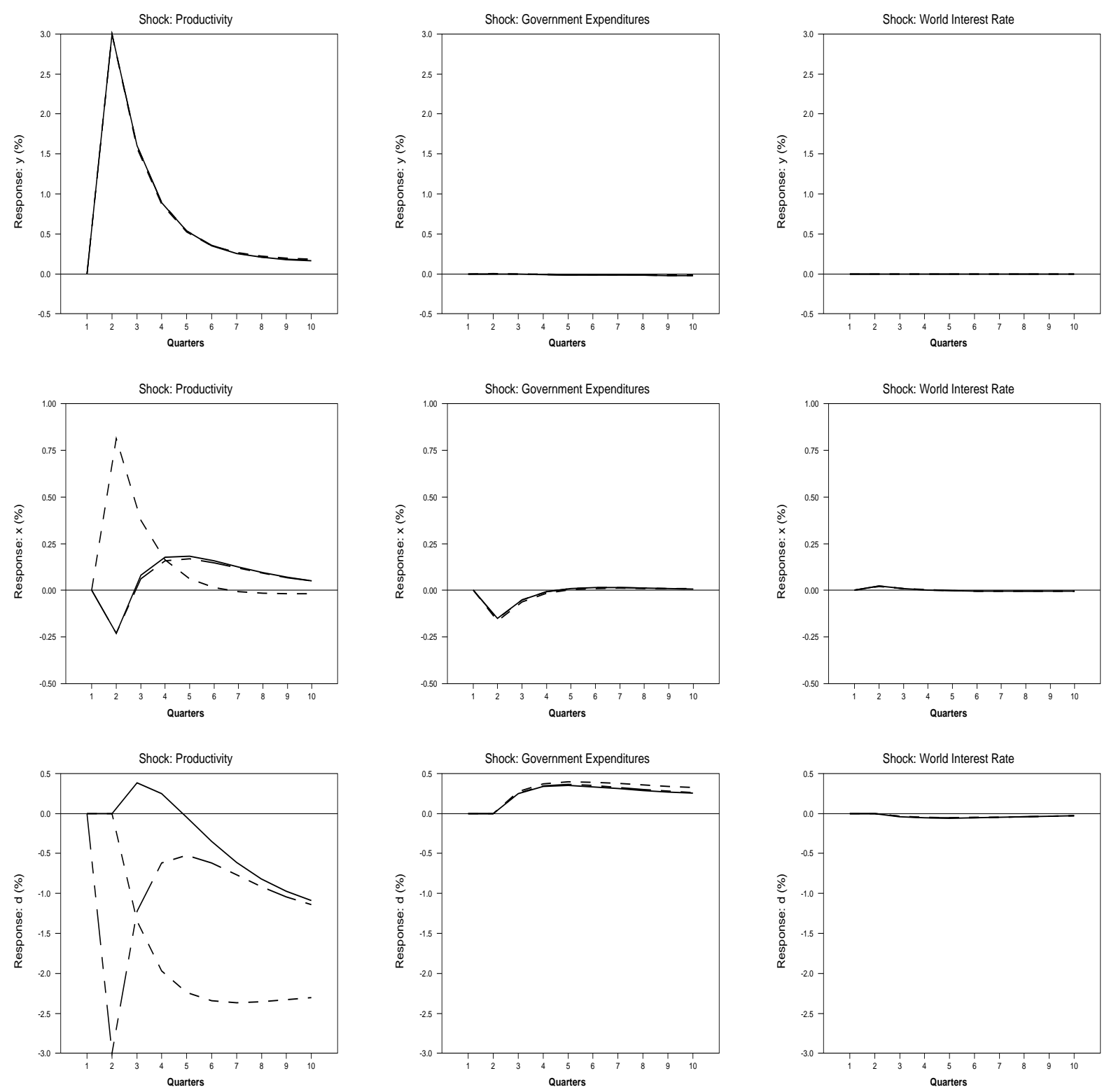

Note: The solid (dashed) [dotted] lines represent the dynamic responses of $y, x$, and $d$ predicted by the baseline (debt-output ratio) [habit formation] versions. The variables are the demeaned logarithm of output $(y)$, the demeaned ratio of the current account to output $(x)$, and the demeaned interest differential $(d)$. 


\section{Figure 2. Cross-Correlation Functions}
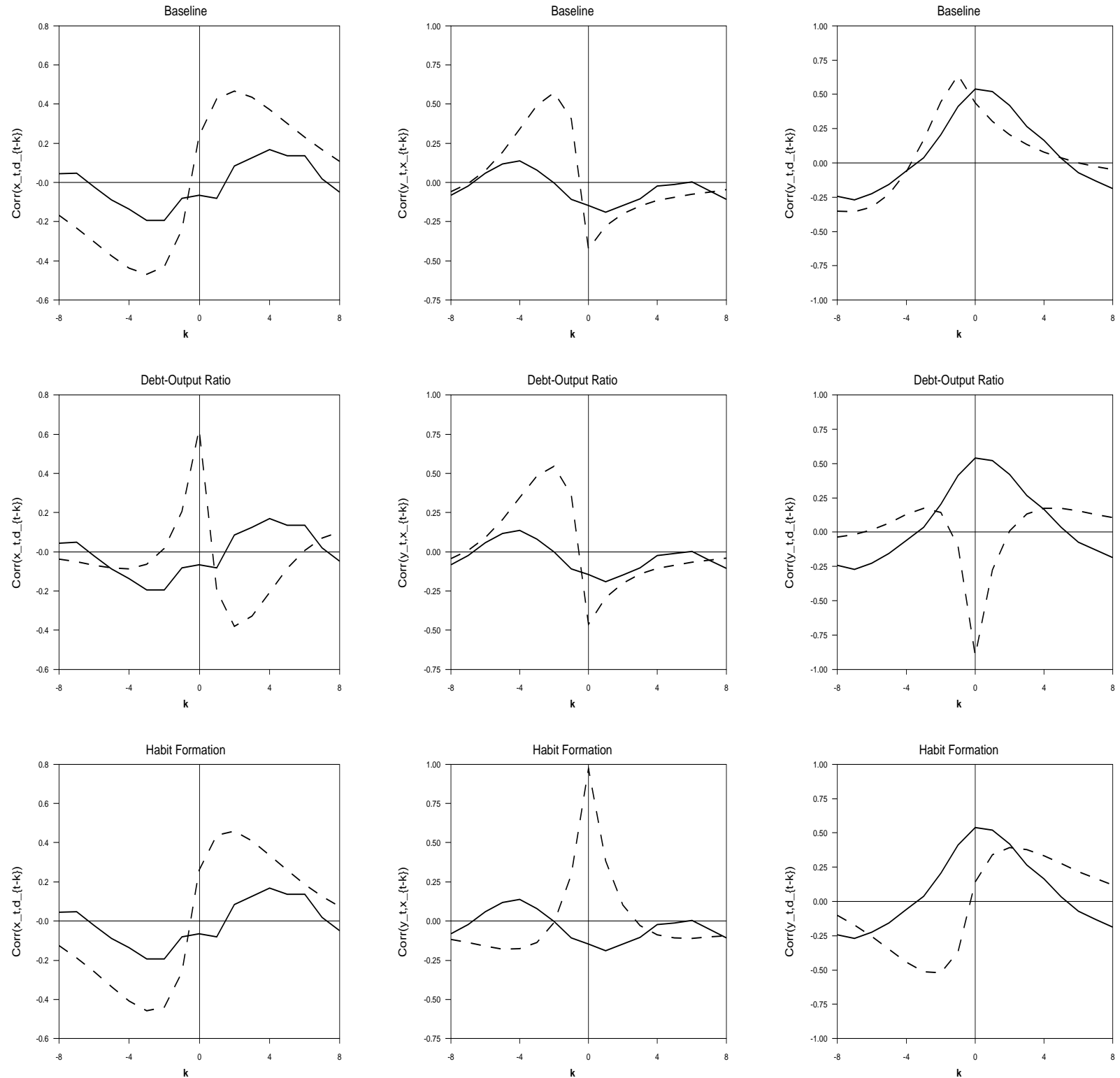

Note: The solid lines are the cross-correlations computed from the Canadian data. The dashed lines correspond to the cross-correlations predicted by the three versions of the model. 
Figure 3. Cross-Correlation Functions:

\section{Sensitivity of the Baseline Parametrization}
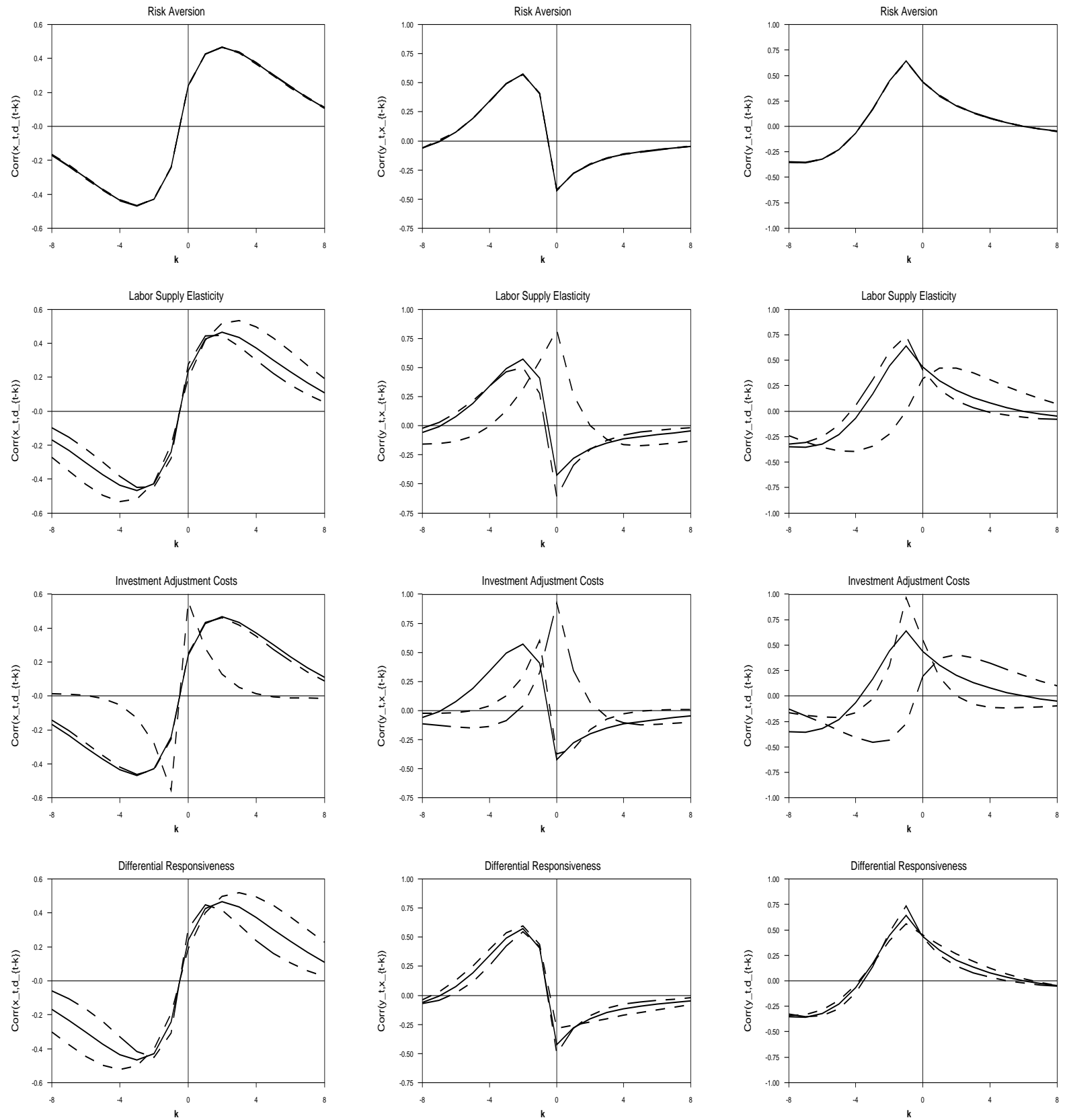

Note: The solid lines are the cross-correlations computed using the Baseline parametrization. The dashed (dotted) lines are the cross-correlations predicted by alternative parametrizations involving low (large) values of key parameters. 


\section{Liste des cahiers de recherche publiés par les professeurs des H.E.C. $2003-2004$}

Institut d'économie appliquée

IEA-03-01 GAGNÉ; ROBERT; LÉGER, PIERRE THOMAS. « Determinants of Physicians’ Decisions to Specialize »,29 pages.

IEA-03-02 DOSTIE, BenOIT. «Controlling for Demand Side Factors and Job Matching: Maximum Likelihood Estimates of the Returns to Seniority Using Matched Employer-Employee Data »,24 pages.

IEA-03-03 LAPOINTE, ALAIN. « La performance de Montréal et l'économie du savoir: un changement de politique s'impose », 35 pages.

IEA-03-04 NORMAndin, MICHel; PhAneuf, LOUIS. « Monetary Policy Shocks: Testing Identification Conditions Under Time-Varying Conditional Volatility », 43 pages.

IEA-03-05 BOILEAU, MARTIN; NORMANDin, MICHEL. «Dynamics of the Current Account and Interest Differentials », 38 pages.

IEA-03-06: NORMANDIN, MICHEL; ST-AMOUR, PASCAL. « Recursive Measures of Total Wealth and Portfolio Return », 10 pages.

IEA-03-07: DOSTIE, BENOIT; LÉGER, PIERRE THOMAS. « The Living Arrangement Dynamics of Sick, Elderly Individuals », 29 pages.

IEA-03-08: NORMANDIN, MICHEL. « Canadian and U.S. Financial Markets: Testing the International Integration Hypothesis under Time-Varying Conditional Volatility », 35 pages. 
IEA-04-01: LEACH, ANDREW. «Integrated Assessment of Climate Change Using an OLG Model », 34 pages.

IEA-04-02: LEACH, ANDREW. "SubGame, set and match. Identifying Incentive Response in a Tournament », 39 pages.

IEA-04-03: LEACH, ANDREW. « The Climate Change Learning Curve », 27 pages.

IEA-04-04: DOSTIE, BENOIT; VENCATACHELLUM, DÉSIRÉ. « Compulsory and Voluntary Remittances: Evidence from Child Domestic Workers in Tunisia », 46 pages.

IEA-04-05: RENGIFO, E.W.; ROMBOUTS, J.V.K. « Dynamic Optimal Portfolio in a VaR Framework », 33 pages.

IEA-04-06: DOSTIE, BENOIT; TRÉPANIER, MATHIEU. « Return to Computer Use and Organizational Practices of the Firm », 41 pages.

IEA-04-07: ALLARD, MARIE; LÉGER, PIERRE THOMAS; ROCHAIX, LISE. « Provider Competition in a Dynamic Setting » 32 pages

IEA-04-08: MAURICE N. MARCHON. «Perspectives économiques canadiennes dans un contexte international » 27 pages 